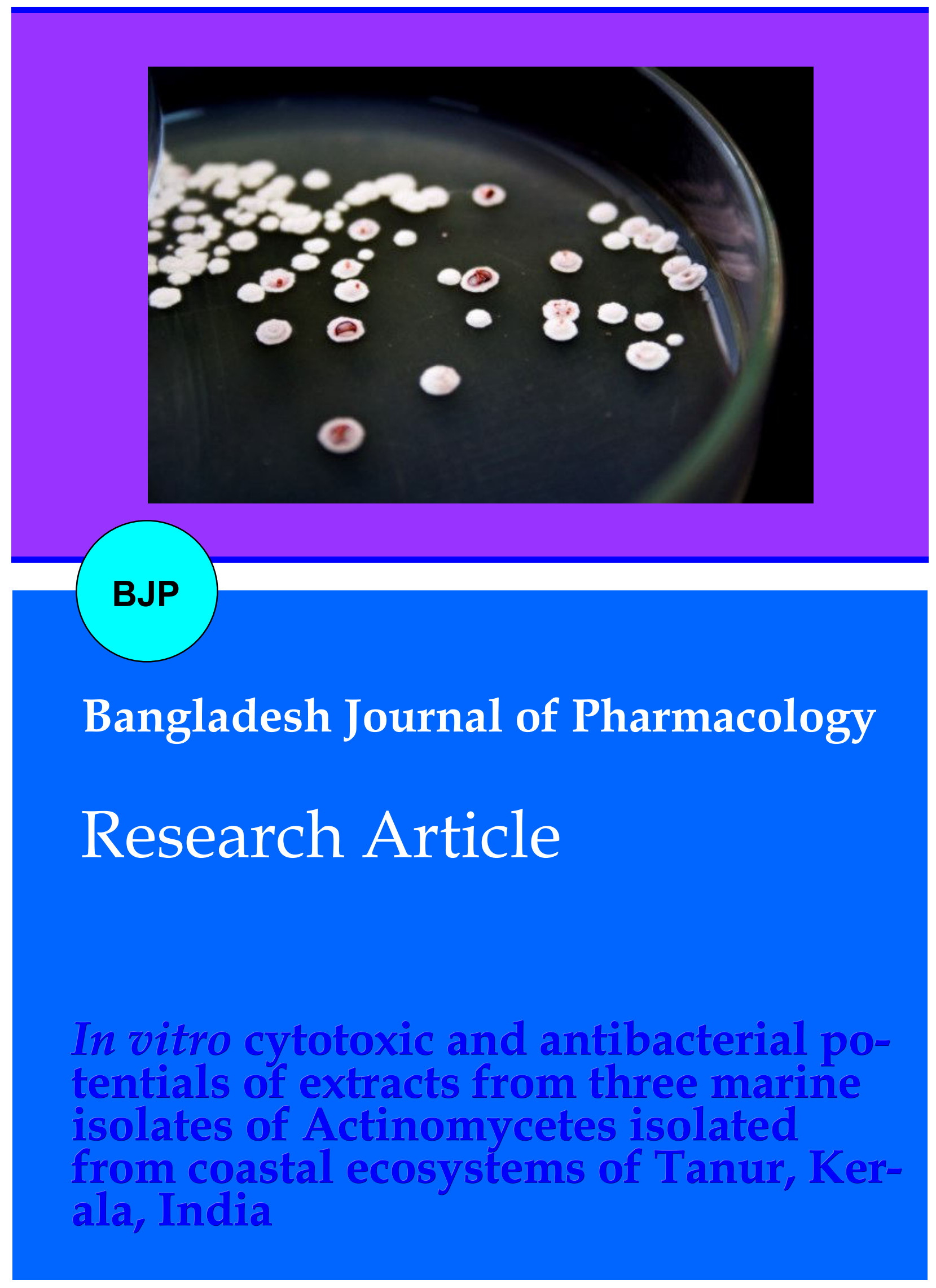




\title{
In vitro cytotoxic and antibacterial potentials of extracts from three marine isolates of Actinomycetes isolated from coastal ecosystems of Tanur, Kerala, India
}

\author{
Kuruvalli Prashanthi and Kilingar Nadumane Varalakshmi \\ Department of Biotechnology, Centre for Post-Graduate Studies, Jain University, Jayanagar, Bangalore 560011 ,
} Karnataka, India.

\begin{tabular}{|c|c|}
\hline Article Info & \\
\hline Received: & 2 December 2014 \\
\hline Accepted: & 29 December 2014 \\
\hline Available Online: & 16 January 2015 \\
\hline DOI: $10.3329 /$ bjp.v & 10i1.21085 \\
\hline $\begin{array}{l}\text { Cite this article: } \\
\text { Prashanthi K, Va } \\
\text { vitro cytotoxic and } \\
\text { tials of extracts } \mathrm{f} \\
\text { isolates of Actin } \\
\text { from coastal ecos } \\
\text { Kerala, India. Ban } \\
\text { col. 2015; 10: 57-62. }\end{array}$ & $\begin{array}{l}\text { ralakshmi KN. In } \\
\text { antibacterial poten- } \\
\text { rom three marine } \\
\text { omycetes isolated } \\
\text { ystems of Tanur, } \\
\text { gladesh J Pharma- }\end{array}$ \\
\hline
\end{tabular}

\begin{abstract}
Three Actinomyctes with potential bioactivity are successfully isolated from the marine water samples and identified as Prauserella marina, Streptomyces sindenensis and S. spiroverticillatus. The ethyl acetate extracts from the three Actinomycetes are found to have significant bioactivity. The highest antibacterial activity was given by the extract from $P$. marina on B. cereus showing $28 \mathrm{~mm}$ of zone of inhibition. Cytotoxicity screening of the crude extracts using 3-(4, 5-dimethylthiazol-2yl)-2, 5-diphenyl tetrazolium bromide (MTT) cell viability assay revealed that extract from $P$. marina noticeably effected the viability of the human cervical cancer cell grown in vitro. Thin layer chromatography of the crude extract with methanol and chloroform (8:2) as solvent system yielded three distinct fractions, of which fraction with Rf value 0.8 resulted in 77, 68, 54 and $40 \%$ growth inhibition of HeLa cells at 15, 10, 5, $2.5 \mu \mathrm{g} / \mathrm{mL}$, respectively with the IC 50 value as $3.3 \mu \mathrm{g} / \mathrm{mL}$. HPLC analysis of the fraction resulted in single major peak at $3.7 \mathrm{~min}$.
\end{abstract}

\section{Introduction}

Actinomycetes are Gram-positive filamentous organisms best known as major source of antibiotics. They belong to the order Actinomycetales (Super-kingdom: Bacteria, Phylum: Firmicutes, Class: Actino-bacteria) (Ventura et al., 2007). Among Actinomycetes, majority of the antibiotics are produced by Streptomyces species. Members of this group of bacteria are the producers of vast variety of bioactive compounds with applications in several fields (Berdy, 2005). Despite the advancement in the knowledge of cancer induction and progression, cancer still remains one of the most fatal illnesses affecting human health (Olano et al., 2009). Chemotherapy is one of the most preferred treatments of choice for cancer. Many clinically useful antitumor drugs such as anthracyclines (aclarubicin, daunomycin and doxorubicin), peptides (bleomycin and actinomycin D), aureolic acids (mithramycin), enediynes (neocarzinostatin), antimetabolites (pentostatin), carzinophilin, mitomycins and others are produced by Actinomycetes. With the rapid development of resistance to multiple chemotherapeutic agents, high toxicity to drugs and a significant number of side effects, there is a need to search for novel chemotherapeutic agents (Newman and Cragg, 2007).

Marine Actinomycetes are widely distributed in different marine ecosystems and are largely unexplored. To ensure survival in environments like extreme pressure, temperature and $\mathrm{pH}$, marine Actinomycetes have acquired unique metabolic and physiological capabilities (Haefner, 2003; Bull and Stach, 2007). As there is difference in the characteristics of marine Actinomycetes from their terrestrial counterparts, the secondary metabolites from marine source may be promising as bioactive compounds (Stach et al., 2003; Jensen et al., 2005). The present study is an attempt to explore the possibilities of finding a novel chemotherapeutic agent against cancer and bacterial human pathogens from 
three Actinomycetes isolated from costal marine ecosystem.

\section{Materials and Methods}

\section{Collection of water sample}

Marine water samples for the current study were collected from different locations around Tanur beach, Malappuram district, Kerala, India (10.97N 75.86E), in sterile containers and were stored at $4^{\circ} \mathrm{C}$.

\section{Isolation and morphological characterization}

Isolation was carried out by serial dilution and spread plate technique (Kumar et al., 2010). The dilutions were made in sterilized marine water up to $10^{-5}$ dilutions and were spread on Starch Casein Nitrate Agar (SCNA) medium with tetracycline and fluconazole added to inhibit the growth of bacteria and fungi respectively. The cultures were incubated for 7 days at $28^{\circ} \mathrm{C}$. Pure cultures were obtained by subculturing on slants containing SCNA and maintained at $4^{\circ} \mathrm{C}$ for further study. Actinomycetes were identified by comparing their colony morphology (Oskay et al., 2005), sporebearing hyphae and structure of spore chain with the Actinomycetes morphologies, as described elsewhere (Cross 1989; Goodfellow 1989).

\section{Molecular characterization and phylogenetic analysis}

Actinomycete isolates were cultured in SCN broth and incubated for 5 days at $28^{\circ} \mathrm{C}$ at $150 \mathrm{rpm}$. The cell mass was filtered and used for genomic DNA isolation. DNA extraction was carried out using genomic DNA isolation kit (Chromus Biotech Pvt. Ltd., Bangalore, India). Specific sequence amplification was performed using universal 16S rDNA primers (Schwieger and Tebbe 1998). The reaction was set in a total $25 \mu \mathrm{L}$ reaction mixture in sterile $0.2 \mathrm{~mL}$ PCR vials. The reaction mixture contained the following components: $1.5 \mu \mathrm{L}$ of genomic DNA, 10 picomoles of $16 \mathrm{~S}$ rDNA forward primer (5' - AGAGTTTGATCCTGGCTCA - 3'), 10 picomoles of $16 S$ rDNA reverse primer (5' - ACGGCTACCTTGTTACGACT - 3'), $1 \mu \mathrm{L}$ of $30 \mathrm{mM}$ deoxyribonucleoside $5^{\prime}$ triphosphate (all the dNTPs in equimolar concentration), $2.5 \mu \mathrm{L}$ of 10X PCR assay buffer and $1 \mu \mathrm{L}$ of Taq DNA polymerase enzyme (1U) (Chromus Biotech Pvt. Ltd., Bangalore, Karnataka, India). Sterile distilled water was added to make up the volume to 25 $\mu \mathrm{L}$. The vials were then set in thermal cycler (MJ research, PTC 200) for amplification with the following program: initial denaturation at $94^{\circ} \mathrm{C}$ for $2 \mathrm{~min}$, followed by 30 cycles of denaturation $-1 \mathrm{~min}$ at $94^{\circ} \mathrm{C}$, annealing $-30 \mathrm{sec}$ at $57^{\circ} \mathrm{C}$ and extension $-1 \mathrm{~min}$ at $74^{\circ} \mathrm{C}$. The program ended with final extension step - $5 \mathrm{~min}$ at $74^{\circ} \mathrm{C}$. The amplified product was analyzed on $1 \%$ agarose gel and documented using gel documentation system (Herolabs, Germany). The amplified PCR product was then sequenced at Chromus Biotech Pvt. Ltd., Bangalore, Karnataka, India, for obtaining partial sequence. The sequences were analyzed using Molecular Evolutionary Genetics Analysis software (MEGA, version 6.05) (Tamura et al., 2011) and aligned together with reference sequences obtained from the GeneBank, EMBL and DDBJ using the CLUSTAL W program included in MEGA 6.05. Phylogenetic trees were constructed using the software MEGA 6.05 based on the neighbor-joining method (Saitou and Nei, 1987; Tamura et al., 2011). The topology was built by the bootstrap method (1,000 replicates) (Felsenstein, 1985).

\section{Ethyl acetate extraction}

The antagonist Actinomycetes were inoculated in $50 \mathrm{~mL}$ yeast extract malt extract (Shirling and Gottlieb, 1966) broth and incubated at $28^{\circ} \mathrm{C}$ in a shaker incubator at 150 rpm for 10 days. The culture was filtered and to the filtrate equal volume of ethyl acetate was added. The filtrate with ethyl acetate was shaken vigorously for 1 hour. The ethyl acetate fraction was collected using a separating funnel. The solvent was then evaporated, and the extracts were dissolved in DMSO at a concentration of $1 \mathrm{mg} / \mathrm{mL}$ for testing the cytotoxicity and antibacterial activity.

\section{TLC fractionation}

TLC separation was performed using commercially available silica plates. The solvent mix-ture for the TLC fractionation was optimized by trial and error method. For each trial, a $1 \mathrm{~cm} \times 6 \mathrm{~cm}$ silica plate was used and the sample was spotted using a thin capillary tube just 1 $\mathrm{cm}$ above the bottom of the plate. The solvent systems with chloroform, methanol, ethyl acetate and water were tested with different combina-tions. The silica plate was kept in a closed chamber with the mobile phase and run till the solvent reached the top end of the plate. The plate was then dried, and the spots were detected by exposing the plate to UV light and iodine vapors. The distance of each spot from the origin was measured and Rf values were calculated. For the preparative TLC, the fractions were scraped care-fully from the TLC plates and dissolved in methanol. The silica particles were separated by centrifugation, and each fraction was tested for cytotoxic and antibacterial activity (Kirchner et al., 1951).

Cytotoxicity Testing - MTT [3-(4, 5-dimethylthiazol2yl)-2, 5-diphenyl tetrazolium bromide] cell viability assay

HeLa cells were seeded in 96-well flat-bottom microplates and cultured in a $\mathrm{CO}_{2}$ incubator (at $37^{\circ} \mathrm{C}$ with $5 \% \mathrm{CO}_{2}$ and $95 \%$ air) for adhesion overnight. The ethyl acetate extracts at 50, 25 and $10 \mu \mathrm{g} / \mathrm{mL}$ and TLC purified frac-tions at $15,10,5$ and $2.5 \mu \mathrm{g} / \mathrm{mL}$ concentration were added to the ELISA plate, and the plate was incubated for 24 hours, each in 
quadruplicates. Following the incubation, $100 \mu \mathrm{L}$ of MTT solution was added. The culture was then incubated for 3 hours in dark chamber for the conversion of MTT to formazan. Thereafter, the supernatant was aspirated and $100 \mu \mathrm{L}$ of DMSO was added to dissolve the formazan. The absorbance was recorded at $540 \mathrm{~nm}$ with the help of ELISA plate reader (Mosmann, 1983). The percentage viability was calculated using the following formula:

Percentage viability $(\%)=\left(\mathrm{A}_{540}\right.$ of the test sample $) /$ (A $\mathrm{A}_{540}$ of the control) X 100

\section{Preliminary antimicrobial activity screening}

Isolates were preliminarily tested for antimicrobial activity by cross-streak method on SCNA plates (Sateesh et al., 2011). After incubation at $28^{\circ} \mathrm{C}$ for 6 days, 24-hour cultures of bacteria were streaked perpendicular to the central strip of Actinomycetes culture, the plates were incubated at $30^{\circ} \mathrm{C}$ for 24 hours and zone of inhibition was noted. The clinical isolates of Staphylococcus aureus, Escherichia coli, S. citrus, Bacillus subtilis, Proteus mirabilis, Salmonella typhi, Klebsiella, Bacillus polymyxa, Serratia marcescens and Pseudomonas sp. were used in the study.

\section{Antibacterial activity and zones of inhibitions}

Antimicrobial activities of the extracts were tested against different Gram-positive and Gram-negative bacteria using agar well diffusion method (Bauer et al., 1966). Nutrient broth was used for culturing the bacteria. The overnight grown bacterial cultures $(100 \mu \mathrm{L}$ each) were spread on Muller Hilton agar plates. A cork borer with a diameter of $6.0 \mathrm{~mm}$ was used for punching the wells on the agar plates. Control and sample extracts (50 $\mu \mathrm{L}$ each) were loaded on to the wells. The inhibition zones around the wells were measured after 24 hours of incubation at $37^{\circ} \mathrm{C}$.

\section{HPLC analysis of bioactive fraction}

The bioactive fraction from Prauserella marina JUACT 04 was analyzed using reverse phase HPLC. The analysis was performed using WATERS HPLC system with binary pump and dual $\lambda$ absorbance UV detector. The column used was C-18 YMC with $3 \mu \mathrm{m}$ particle size. The mobile phase consisted of $80: 20$ of water: methanol (Snyder et al., 2012).

\section{Results}

The pure culture colonies of the three Actinomycete isolates were obtained up on serial dilution and were maintained by subculturing on starch casein nitrate agar medium (Figure 1). In the preliminary examination of the morphological and colony characters, the three bacteria isolated from the marine samples were identified as members of the class Actinobacteria.
Further molecular characterization using $16 \mathrm{~S}$ rDNA analyses resulted in the identification of the organisms as P. marina JUACT 04; Streptomyces sindenensis JUACT 06; S. spiroverticillatus JUACT 05. The phylogenetic analysis revealed that $P$. marina JUACT 04 shows highest affinity with P. marina strain Ms498 by $96 \%, S$. sindenensis JUACT 06 with $S$. sindenensis strain NBRC 3399 by $89 \%$ and $S$. spiroverticillatus JUACT 05 with $S$. spiroverticillatus strain NBRC 12821 by $98 \%$ bootstarp level (Figure 2).

The cross streak method of testing was useful in quickly screening the antibiotic properties of the three isolates. It was found that all the three isolates were inhibiting

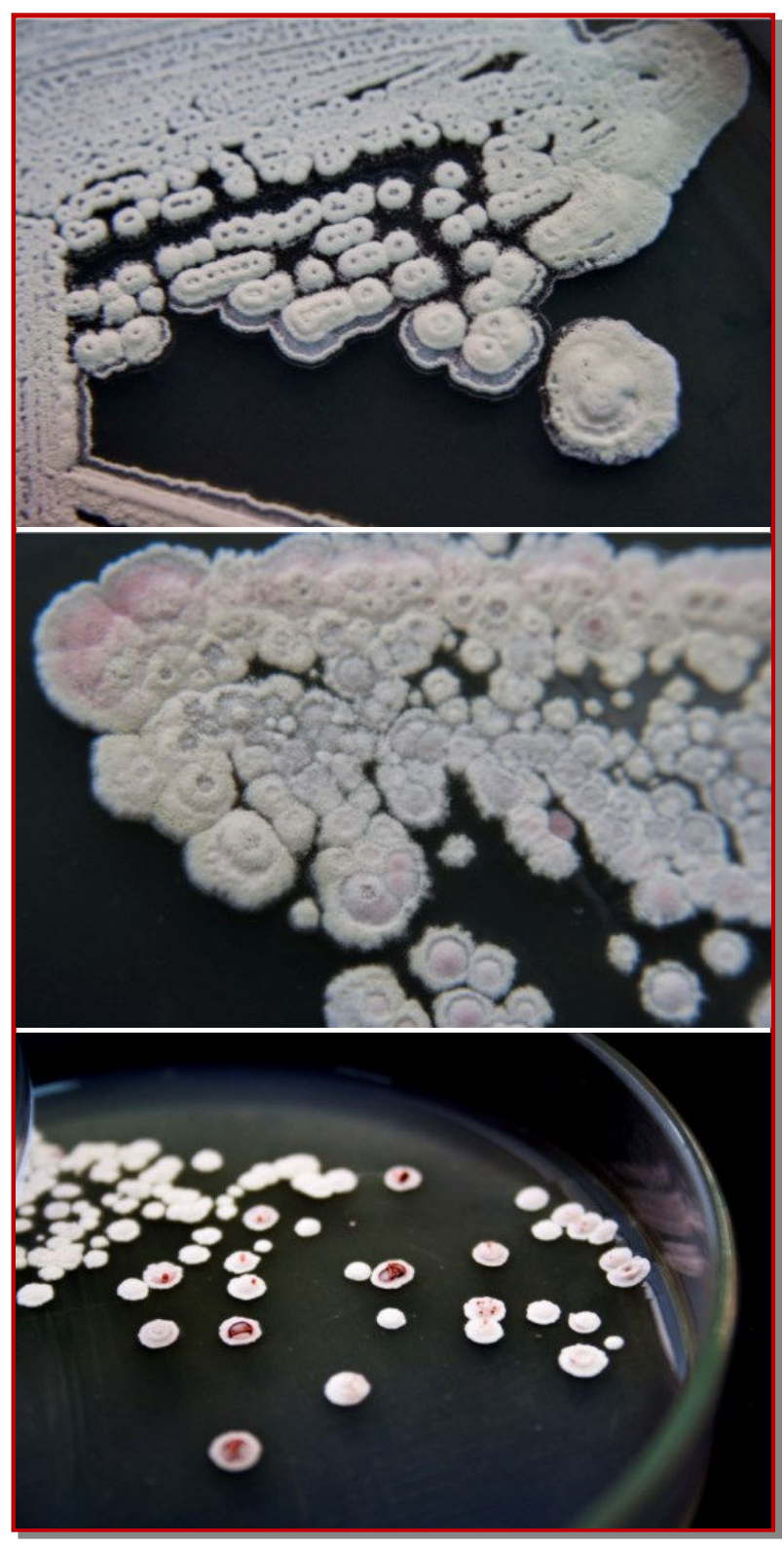

Figure 1: Pure cultures of the marine isolates (A) Prauserella marina JUACT 04, (B) Streptomyces spiroverticillatus JUACT 05 and (C) Streptomyces sindenensis JUACT 06 


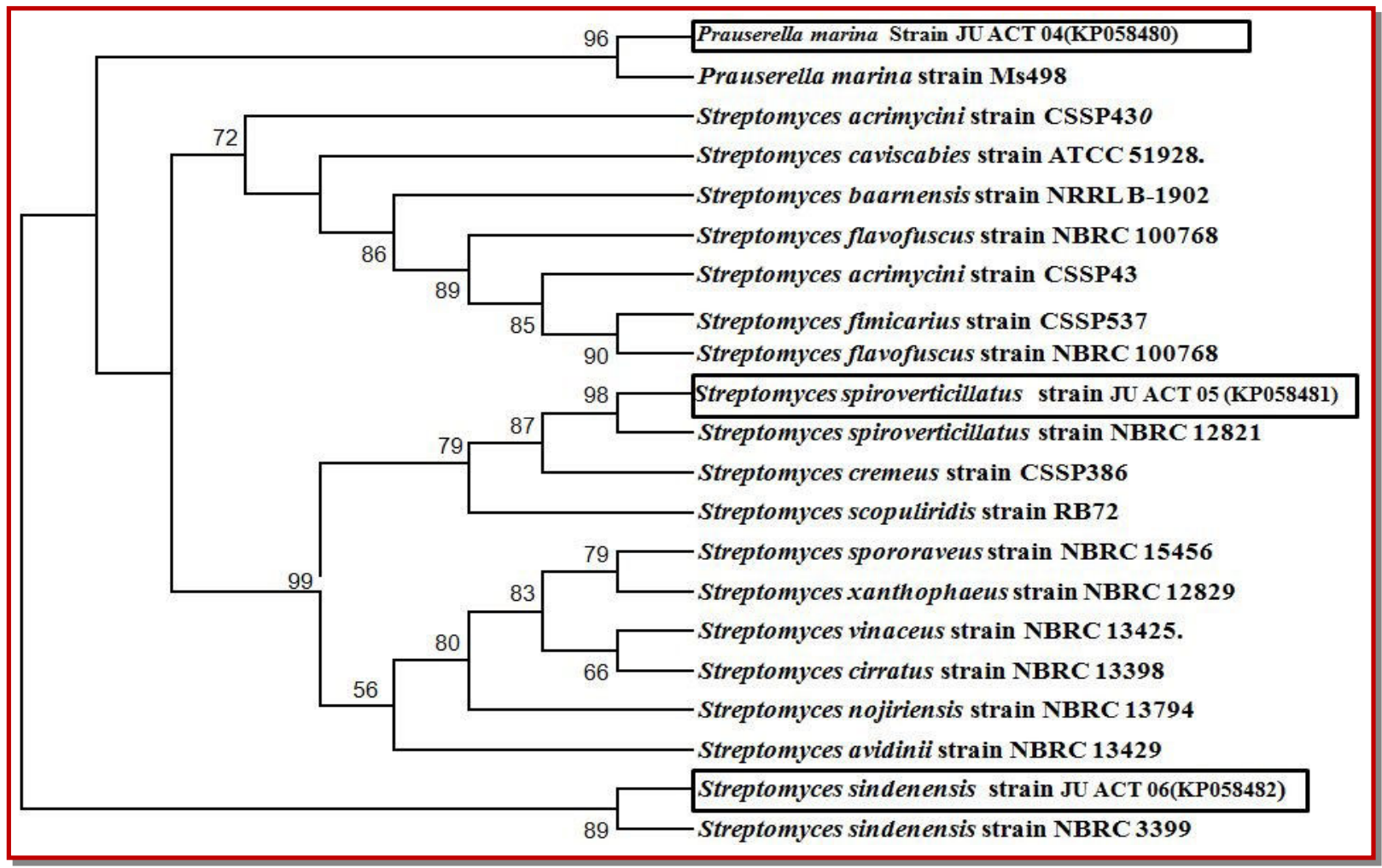

Figure 2: Molecular phylogenetic analysis by maximum likelihood method. The bootstrap consensus tree inferred from 1000 replicates is taken to represent the evolutionary history of the taxa analyzed. Branches corresponding to partitions reproduced in less than $50 \%$ bootstrap replicates are collapsed. The percentage of replicate trees in which the associated taxa clustered together in the bootstrap test (1,000 replicates) is shown next to the branches. Initial tree(s) for the heuristic search were obtained automatically by applying the Maximum Parsimony method. The analysis involved 21 nucleotide sequences. Evolutionary analyses were conducted in MEGA6

\section{Table I}

Antimicrobial activity of the extracts

\begin{tabular}{|c|c|c|c|}
\hline \multirow{2}{*}{$\begin{array}{l}\text { Test patho- } \\
\text { gen }\end{array}$} & \multicolumn{3}{|c|}{ Zone of inhibition (mm) } \\
\hline & $\begin{array}{c}\text { Extract from } \\
\text { P. marina } \\
\text { JUACT } 04\end{array}$ & $\begin{array}{l}\text { Extract from } \\
\text { S. spiroverticil- } \\
\text { latus JUACT } 05\end{array}$ & $\begin{array}{l}\text { Extract from } \\
\text { S. sindenensis } \\
\text { JUACT } 06\end{array}$ \\
\hline $\begin{array}{l}\text { Staphylococ- } \\
\text { cus aureus }\end{array}$ & $22 \pm 0.2$ & $10 \pm 0.3$ & $10 \pm 0.2$ \\
\hline $\begin{array}{l}\text { Staphylococ- } \\
\text { cus citreus }\end{array}$ & $16 \pm 0.1$ & $10 \pm 0.2$ & $10 \pm 0.1$ \\
\hline $\begin{array}{l}\text { Bacillus cere- } \\
\text { us }\end{array}$ & $28 \pm 0.1$ & $10 \pm 0.2$ & $26 \pm 0.2$ \\
\hline $\begin{array}{l}\text { Escherichia } \\
\text { coli }\end{array}$ & $24 \pm 0.4$ & Nil & $22 \pm 0.3$ \\
\hline $\begin{array}{l}\text { Proteus mira- } \\
\text { bilis }\end{array}$ & $20 \pm 0.2$ & Nil & $18 \pm 0.2$ \\
\hline Salmonella & $15 \pm 0.2$ & $10 \pm 0.1$ & $10 \pm 0.1$ \\
\hline Klebsiella & $10 \pm 0.1$ & Nil & $18 \pm 0.1$ \\
\hline $\begin{array}{l}\text { Bacillus poly- } \\
\text { myxa }\end{array}$ & $20 \pm 0.1$ & $11 \pm 0.4$ & $12 \pm 0.2$ \\
\hline $\begin{array}{l}\text { Pseudomonas } \\
\text { aeruginosa }\end{array}$ & $20 \pm 0.1$ & $11 \pm 0.2$ & $26 \pm 0.2$ \\
\hline
\end{tabular}

the growth of one or the other pathogenic bacteria tested. This was indicated by the clearing zone near the Actinomycetes steaks. The ethyl acetate extracts when tested against bacterial human pathogens resulted in zones of inhibition ranging from $10 \mathrm{~mm}$ diameter to $28 \mathrm{~mm}$ diameter, indicating potential antibacterial properties of the extracts. It was found that the extract from $P$. marina JUACT 04 and $S$. sindenensis JUACT 06 inhibited the growth of all the nine human pathogenic bacteria tested. The extract from S. spiroverticillatus JUACT 05 showed poor inhibitory effect on the growth of pathogenic bacteria indicated by small zones of inhibition. Also, the extract did not show any inhibitory effect on the growth of E. coli, Proteus mirabilis and Klebsiella clearly indicated by no zone of inhibition (Table I).

In case of cytotoxicity screening using MTT assay, the extract from $P$. marina JUACT 04 alone was able to inhibit the growth and viability of the human cervical cancer cell line HeLa. Further, the TLC fractionation of the extract resulted in three fractions among which the fraction with $\mathrm{Rf} 0.8$ value showed notable cytotoxicity.

The percentage viability of HeLa cells was found to be $23,32,46$ and $60 \%$ with $15,10,5$ and $2.5 \mu \mathrm{g} / \mathrm{mL}$ 


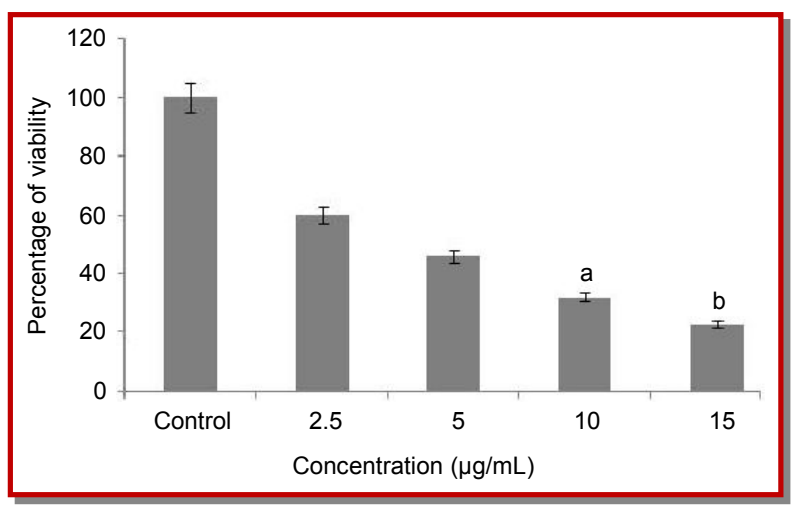

Figure 3: Effect of TLC purified fraction with Rf value 0.8 from P. marina JUACT 04 on HeLa cells analyzed by MTT Cell viability assay; ${ }^{\mathrm{p}}<0.05, \mathrm{~b} p<0.005$ for novel therapeutic agents to fulfill the unmet medical needs (Wright and Sutherland, 2007). Marine environments form an excellent source for vast variety of microorganisms. Actinomycetes are one such group in marine ecosystems that are up-and-coming as a source of novel bioactive compounds. Actinomycetes are widely distributed in different marine ecosystems like deep sea floor, surface of the oceans such as in the near shore and intertidal environments, marine sediments, coral reefs, invertebrates and marine plants (Jensen et al., 2005). Marine Actinomyceteshave evolved historically resulting in great metabolic and genomic diversity. The exploitation of marine Actinomycetesas a source for novel antibiotic and cytotoxic compounds is still in its infancy. P. marina JUACT 04 isolated from marine sediments is promising as it is found to possess

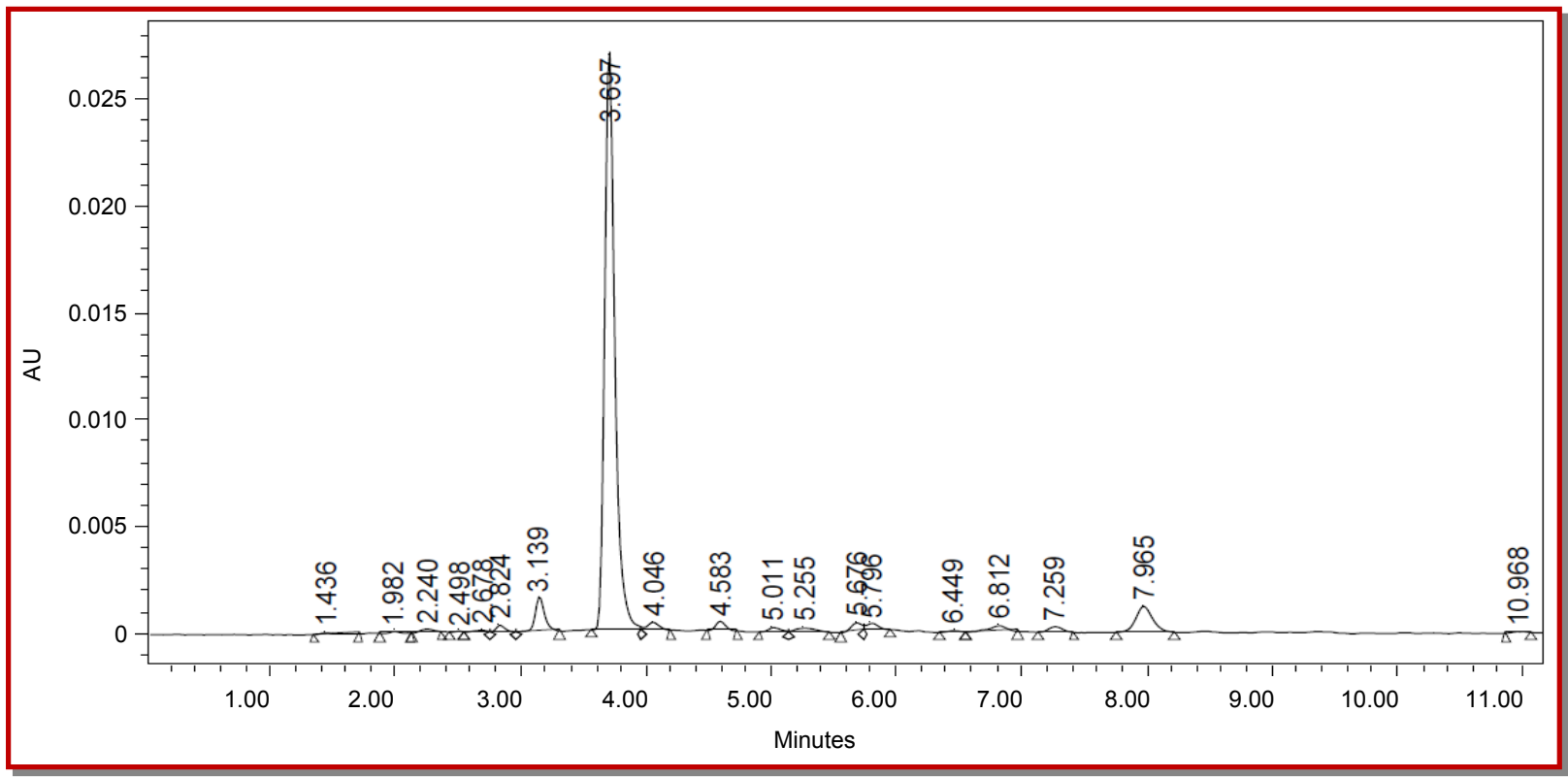

Figure 4: HPLC analysis of bioactive fraction from P. marina JUACT 04

(Figure 3). The $\mathrm{IC}_{50}$ value is found to be $3.3 \mu \mathrm{g} / \mathrm{mL}$ indicating anticancer potential of the fraction. In an attempt to further purify and characterize the active component from the TLC fraction, HPLC was performed for the third fraction of the ethyl acetate extract from $P$. marina JUACT 04. The HPLC run resulted in a single large peak with a retention time of $3.7 \mathrm{~min}$. The results of the HPLC run indicate that the TLC fraction was consider-ably pure with the major peak contributing to $96.8 \%$ of the area (Figure 4 ).

\section{Discussion}

Among the 30,000 diseases which are described clinically, less than one third of them can be treated symptomatically and very few can be cured (Subramani and Aalbersberg, 2012). Currently there is an urgent need antibiotic and cytotoxic potentials. A similar organism P. marina sp MS498 ${ }^{\mathrm{T}}$ is also found to exist in the ocean sediment of South China Sea (Wang et al., 2010). It is known that rare Actinomycetes produce diverse and unique, extraordinary sometimes very complicated compounds showing excellent bioactivity and usually low to toxicity (Berdy, 2005). Frigocyclinone, glaciapyrroles, gutingimycin and himalomycins are few of the antibacterial compounds that have been discovered from marine Streptomyces sp (Bruntner et al., 2005).The antimicrobial activity of $S$. spiroverticillatus has been reported and is popularly known to produce tautomycin. Tautomycin is a protein phosphatase inhibitor and is structurally close to tautomycetin, a lead for cancer drug. Similarly, the antimicrobial potentials of $S$. sindenensis have been evaluated and found to have significant antibiosis against certain common human bacterial and fungal pathogens (Ningthoujam et al., 
2009). With these findings we conclude that $P$. marina JUACT 04 and $S$. spiroverticillatus JUACT 05 isolated from marine sediments have proven to possess bioactivity. These results provide a justification for further research to purify and evaluate the structural features of the bioactive principle.

\section{Acknowledgement}

The authors wish to sincerely thank the management of Jain Group of Institutions for the infrastructural facilities provided to carry out the work.

\section{References}

Bauer AW, Kirby WM. Sherris J C, Turk M. Antibiotic susceptibility testing by standard single disk method. Am J Clin Pathol. 1966; 45: 493-96.

Berdy J. Bioactive microbial metabolites. J Antibiot (Tokyo). 2005; 58: 1-26.

Bruntner C, Binder T, Pathom-aree W, Goodfellow M, Bull A T, Potterat O, Puder C, Horer S, Schmid A, Bolek W. Frigocyclinone, a novel angucyclinone antibiotic produced by a Streptomyces griseus strain from Antarctica. J Antibiot. $2005 ; 58,346-49$.

Bull AT, Stach JE. Marine actinobacteria: New opportunities for natural product search and discovery. Trends Microbiol. 2007; 15: 491-99.

Cross T. Growth and examination of actinomycetes some guidelines. In: Bergey's Manual of systematic bacteriology. Baltimore, Williams \& Wilkins Company, 1989, pp 2340-43.

Felsenstein J. Confidence limits on phylogenies: An approach using the bootstrap. Evolution 1985; 783-91.

Goodfellow M. Suprageneric classification of Actinomycetes. In: Bergey's Manual of systematic bacteriology. Baltimore, Williams \& Wilkins Company, 1989, pp 2333-39.

Haefner B. Drugs from the deep: Marine natural products as drug candidates. Drug Disc Today. 2003; 8: 536-44.

Jensen P R, Mincer T J, Williams P G, Fenical W. Marine actinomycete diversity and natural product discovery. Antonie Van Leeuw. 2005; 87: 43-48.

Kirchner JG, Miller JM, Keller GJ. Separation and identification of some terpenes by new chromatographic technique. Anal Chem. 1951; 23: 420-25.

Kumar N, Singh RK, Mishra SK, Singh AK, Pachouri UC. Isolation and screening of soil Actinomycetes as source of antibiotics active against bacteria. Int J Microbiol Res. 2010; 2: $12-16$.

Mosmann T. Rapid colorimetric assay for cellular growth and survival: Application to proliferation and cytotoxicity assays. J Immunol Methods. 1983; 65: 55-63.

Newman DJ, Cragg GM. Natural products as sources of new drugs over the last 25 Years. J Nat Prod. 2007; 70: 461-77.

Nigthoujam DA, Sanasam S, Nimaichand SA. A Streptomyces sindenensis strain LS1-128 exhibiting broad spectrum antimicrobial activity. Res J Biol Sci. 2009; 4: 1085-91.

Olano C, Méndez C, Salas JA. Antitumor compounds from Actinomycetes: From gene clusters to new derivatives by combinatorial biosynthesis. Nat Prod Reports. 2009; 26: 62860 .

Oskay AM, Usame T, Cem A. Antibacterial activity of some actinomycetes isolated from farming soils of Turkey. Afr J Biotechnol. 2005; 3: 441-46.

Saitou N, Nei M. The neighbour-joining method: A new method for reconstructing phylogenetic trees. Mol Biol Evol. 1987; 4: 406-25.

Sateesh V, Naikpatil, Rathod J. Selective isolation and antimicrobial activity of rare actinomycetes from mangrove sediment of Karwar. J Ecobiotechnol. 2011; 3: 48-53.

Schwieger F, Tebbe CC. A new approach to utilize PCR-single strand-conformation polymorphism for $16 \mathrm{~S}$ rRNA genebased microbial community analysis. Appl Environ Microbiol. 1998; 64: 4870-76.

Shirling ET, Gottlieb D. Methods for characterization of Streptomyces species. Int J Syst Bacteriol. 1966; 16: 313-40.

Snyder LR, Kirkland JJ, Glajch JL. Practical HPLC method development. John Wiley \& Sons, 2012.

Stach JE, Maldonado LA, Ward AC, Goodfellow M, Bull AT. New primers for the class Actinobacteria: Application to marine and terrestrial environments. Environ Microbiol. 2003; 5: 828-41

Subramani R, Aalbersberg W. Marine actinomycetes: An ongoing source of novel bioactive metabolites. Microbiol Res. 2012; 167: 571-80.

Tamura K, Peterson D, Peterson N, Stecher G, Nei M, Kumar S. MEGA5: Molecular evolutionary genetics analysis using maximum likelihood, evolutionary distance, and maximum parsimony methods. Mol Biol Evol. 2011; 28: 2731-39.

Ventura M, Canchaya C, Tauch A, Chandra G, Fitzgerald GF, Chater K F, Sinderen DV. Genomics of Actinobacteria: Tracing the evolutionary history of an ancient phylum. Microbiol Mol Biol Rev. 2007; 71: 495-548.

Wang J, Li Y, Bian J, Tang SK, Ren B, Chen M, Zhang LX. Prauserella marina sp. nov., isolated from ocean sediment of the South China Sea. Int J Syst Evol Microbiol. 2010; 60: 98589.

Wright GD, Sutherland AD. New strategies for combating multidrug-resistant bacteria. Trends Mol Med. 2007; 13: 26067. 